\title{
From Social Uprising to Legal Form
}

\section{Anastasia Tataryn ${ }^{1}$ (D)}

Published online: 19 December 2018

(C) The Author(s) 2018

\begin{abstract}
Does, or should, social uprising lead to new legal form? Ukraine's current situation following the Revolution of Dignity in 2013-2014, with continuing violent conflict in Donbas and Crimea, suggests that not only is it unclear how a 'new' form is assessed, but existing transitional policies and frameworks are unlikely to be clearly implemented and enforced. An alternative analysis of transformation is necessary to address the conflicting aftermath of uprising within a particular historical and cultural context. The transformation that is happening in Ukraine is a continuum that is intellectual and psychological as much as reforming judicial systems and governance. Thinking transformation differently opens onto narratives, complexity of causes and a plurality of ideas of future, resolutions and justice. Such a shift in thought and analysis, informed by narratives and grounded research, is necessary in order to try to understand the current pursuit of justice in Ukraine.
\end{abstract}

Keywords Conflict transformation · Originary sociality $\cdot$ Social uprising $\cdot$ Thinking anarchically $\cdot$ Transformative justice $\cdot$ Ukraine

Подї Євромайдану стали частиною особистої історії $i$ пам'яті багатьох украӥнців. Утім, Євромайдан як феномен не варто “списувати” у минуле - у розумінні державних та суспільних перетворень, він $\epsilon$ радше контінуумом, відправною точкою трансформації, яка триває $і$ досі $i$, як будь-яка важлива суспільна зміна, потребує рефлексї та осмислення. (Бурлюк, Шаповалова, Зарембо 2017).

The events of EuroMaidan became a part of the individual histories and memories of many Ukrainians. Hence, EuroMaidan as a phenomenon cannot be 'written off' into the past. In our understanding of state and social transformation, it is a continuum of change that continues until today and, as with any

Anastasia Tataryn

atataryn@liverpool.ac.uk

1 School of Law and Social Justice, University of Liverpool, Rm 2.03 Mulberry Court Walnut House, Mulberry Street, Liverpool L7 7EZ, UK 
serious social change, requires reflection and comprehension. (Byrluk et al. $2017)^{1}$

\section{Introduction}

At their height, social uprisings seize public attention and imaginations. Yet when the dust settles these events can be cast off as temporal disruptions that interrupt order, only to usher in a restored governance structure, either new or old. The discursive possibilities for social uprising are limited by assumptions that they are temporary, and their aftermath is identifiable within systems of governance related to the political-economic system (Teitel 2000, p. 3). There is little nuance in post-uprising discourse; transition is assessed according to a presumption that the aspiration of the upheaval, and thus the measure of its success or failure, is a restoration of the (neo) liberal democratic state (Buckley-Zistel et al. 2013; Sharp 2013). Other possibilities, not only of other state forms but alternative assessments of change are largely absent from the lexicon of transitional justice and regime change.

Undoubtedly, participating in a large-scale social revolt impacts an individual's perspective, their relationship to themselves, their country, neighbours and work. Yet this personal transformation rarely influences consideration of the change that uprising and civil revolution would spark in a society, where society is associated with traditional democratic practices such as parliamentary processes and elections. Transitions to a new legal form are perceived through positivism where 'progress' assumes progression to a liberal regime within institutional state structures. Moreover, during transition periods, quiet repression of civil dissent, structural and economic violence may be overlooked.

Nevertheless, the impulse and event of a social uprising only partially concerns the governance structures that shift or remain. Although social uprisings have the potential to change the relationship of individuals to authority, legitimacy, and law, the interruptions or ruptures they cause are on-going - not beholden to one singular event (Butler 2018). Transformations, as opposed to 'transition', challenge linear constitution. Thus, it is difficult, if not impossible, to assess or measure post-uprising transformations through normative transitional frameworks, including transitional justice mechanisms and discourses.

Hence, I present an exercise of anarchical thinking, drawing on post-structural theoretical perspectives, to examine the aftermath of a social uprising. I apply critiques problematising transitional justice both as an idea and as a model to the case study of Ukraine (following the events of 2013-2014), where government and NGOs, including business-actors, entrepreneurs and other non-state actors, are pushing forward reforms in an effort to 'transition' the country to a new modern liberal system. This transition has been assessed, thus far, as either successful or unsuccessful, largely dependent on which formal economic and political measures are being considered, and the end goal of the assessor (e.g. is the transition achieved with a

\footnotetext{
${ }^{1}$ Ukrainian texts translated by the author.
} 
thriving foreign investment market? A transparent judicial system? A resolution to the war with Russia in Eastern Ukraine? Accessible, reliable, regulated healthcare for citizens?). The various interests, actors and events working within Ukraine can lead to endless weighing of changes versus status quo. These debates largely ignore transformations in peoples' own lives, including their perceptions of themselves and their country as constituent elements of society.

My approach to post-uprising transformation, suggested as anarchical thinking, thus integrates ethnographic observations and conversations carried out in Ukraine (2015 and 2017), which illuminate textual data, existing literature and critique pertaining to changes and transformations in post-revolution (the 'Revolution of Dignity' 2013-2014) Ukraine. These expressions and narratives do not claim to be exhaustive; they do not seek to represent the vast demographic diversity present within Ukraine. Rather, drawing on ethnographic traditions of thick description (Geertz 1973) and snowball sampling methods, I draw on anecdotal observations, conversations and semi-structured interviews gained across 3 months (December 2015, July-August 2017) in Kyiv, Lviv, and Kharkiv, Chernivtsi and Odessa (August 2018). ${ }^{2}$ This mixed methodological approach illustrates Ukraine's context in order to allow us to ask the question of what is happening in this so-called transition from social uprising to legal form from a multi-faceted, and grounded, vantage point. ${ }^{3}$ Critical theory and transitional justice literature have already suggested that transitional justice mechanisms impose a liberal, normative model often ignoring historical, geographic and social contexts. Although ostensibly a theoretical reflection, by including observations from conversations, this study seeks to explore a critique of transitional justice and offer theoretical possibilities for thinking otherwise, applied to the complex case of post-uprising Ukraine.

The specific focus on Ukraine brings attention to a state that since $2014^{4}$ is situated uncomfortably in 'transition', 'transformation', and on-going conflict. Transitional $^{5}$ and lustration ${ }^{6}$ laws passed by the government of Ukraine since 2014 attempting to restructure the judicial system have been largely ineffectual at replacing or prosecuting those who sanctioned the violence in 2013-2014 during the Revolution of Dignity (Zabyelina, pp. 70-72). Legal cases and court proceedings have

\footnotetext{
${ }^{2}$ During this time in Ukraine I engaged in conversation with anyone who was willing and interested to speak with me, but also snowballed from existing professional and personal contacts. Most conversations were carried out in Ukrainian, with some use of Russian and English.

3 This paper aims to form the first part of a larger research project that uses Ukraine's Revolution of Dignity as a case study to open up the definition, analysis and methodology of transformation in law. This project involves a mixed methodology of qualitative interviews, images, reflection and critical analysis of existing literature to re-visit theoretical frameworks used to assess transition, transformation, social movement and its jurisprudence. The research has been conducted in accordance to, and with approval of, the University of Liverpool Committee for Research Ethics, 2017.

4 For centuries Ukraine has been a turbulent border region characterised by contestations of empire, governance and resource control. See Reid (2015).

5 The Law of Ukraine No. 1188 VII for judicial reform from April 2014 and the Law of Ukraine No. 1682-VII 'On Government Cleansing' (Lustration Law) which was passed on 9 October 2014.

${ }^{6}$ Lustration is the process of 'cleansing new regime of remnants from the past'. See Popova and April (2014).
} 
been met with delays, persistent deferrals in court, falsifications or disappearance of documents (Interview Kyiv, 30 August 2017). This appears to be an attempt to extinguish any resources that civilians and advocates have to prosecute the perpetrators of violence against peaceful civilians. Similarly, the Anti-Corruption Bureau (NABU) has in 2017 been subsumed under Presidential oversight, thus compromising its objectivity and ability to carry out investigations in the battle against corruption in high office (Interview Kyiv, 30 August 2017). Civil society organisations fear that the Office of the Prosecutor General of Ukraine (PGOU) is too selective in prosecutions and investigations; moreover, critiques of the current government are being suppressed (Interviews Kyiv, July and August 2017). The Revolution of Dignity offers a specific event ${ }^{7}$ through which to think about how law and social change is assessed 'post' revolution, and how a shift in analysis to focus on change amongst people-thought of as beings in the territory of the state-can reveal a sociality that is transforming, in movement. This sociality may not fit identified categories of transition and reform. And yet, when considered through an alternate lens, one that thinks anarchically, it forms a foundational element of law itself.

A brief overview contextualising the place and events now referred to as the Revolution of Dignity (2013-2014) will lead into a discussion of current approaches to transition and reform in Ukraine, including International Criminal Court (ICC) prosecutions, lustration, reforms of the Supreme Court, economic decentralisation and, briefly, foreign investment. Currently these transitional projects are being led by internal Ukrainian government actors, as well as local and international NGOs, and investors (business actors). However, these projects garner little consistent satisfaction, and increasingly, suffer repression. Current measures situate the uprising in Ukraine as yet again failing to institute significant reform. But the gaps, limitations and inefficacy of traditional 'transition' approaches urge us to re-consider the very prism through which change and transformation is assessed. I suggest that the project of economic decentralisation in Ukraine opens onto the possibility of looking beyond conventional governance to recognise originary sociality as a site of transformative movement, beyond and in excess of state-centred legal and economic reform.

\section{Transition and Sociality: What Are We Looking For?}

Mainstream accounts regularly assess the aftermath of violent civil upheaval, or revolution, by focusing on formal governance or legal administration. Indicators of economic growth, employment, democratic participation, and rates of corruption are used to evaluate a successful transition from one leadership to another, or from one system e.g. colonial or soviet rule, to another e.g. liberal democracy (Sawka 2017). Brinkerhoff identifies the three areas of post-conflict reform as '(1) reconstituting legitimacy, (2) re-establishing security and (3) rebuilding effectiveness' (Brinkerhoff

\footnotetext{
7 Jean-Luc Nancy describes event as: 'what makes an event an event is not only that it happens, but that it surprises' (Nancy 2000, p. 159).
} 
2005, p. 5). Nevertheless, he acknowledges that the context and history of each conflict shape how legitimacy, security and effectiveness can be restored or implemented. In contrast, the following analysis focuses on how transformation, transition and change are experienced, or not, according to perspectives gathered from publications, conversations and observations in five cities of Ukraine: Kyiv (central), Kharkiv (north eastern), Chernivtsi (south western), Lviv (west) and Odesa (south). This approach draws on encounter-interview methods, which are grounded and observational. While these observations are my own, and based on people I encountered and spoke to in the winter of 2015 and summer of 2017 in these 5 regions of Ukraine (lawyers, activists, NGO directors, civil servants, market sellers, landlords, teachers, priests, taxi drivers, bus drivers and academics-history and jurisprudence, about 50/50 male and female, between the ages of 24-75), I draw on these insights to further problematise predetermined models that are implemented universally, but are detached from experiences on the ground. Moreover, speaking with people across Ukraine imbues my work with experiences that constitute what Jean-Luc Nancy has termed 'originary sociality' (Nancy 1991, 2000).

Originary sociality refers to the coming together of people, people who each are singular beings but whose coming together forms a plurality of singular beings. We are thus all 'beings singular plural', and 'being singular plural' is the very basic constitution of a sociality. Our sociality forms a common, a communal plurality that abides by systems of behaviour, frameworks of rules and organisation, informed but not determined by history. For Nancy, sociality is distinguished from 'community' because community implies some kind of determination, or pre-existing bond. The sociality, in contrast, is not predetermined but, vitally, is originary every time that people-singular beings - come together. Thus, in every coming together of the singular plural the sociality is re-constituted. Originary sociality, therefore, has the potential to be original every time that people come together. In other words, there is every possibility of difference or for surprise within sociality to affect or transform normalised systems of organisation and behaviour.

Originary sociality offers a prism through which we may fundamentally question transformation and change after uprising and violence. The focus on multi-dimensional analysis methodologically and conceptually shifts from approaches that focus on assessing social change through formal political, legal and economic transitions. Moreover, originary sociality, when thought of in the context of post-uprising transformations, challenges analyses to consider the fundamental subjects of uprisings: the coming together of people, originally forming a sociality. Informed by originary sociality, the approach to questions of social uprising leading to legal form, or not, or changing the shape of what is a legal form, are narrative, situated and, as will be explained later, anarchic (Newman 2015, pp. 54-55). Such an approach is useful in the wake of increasingly popular critiques of transitional justice and post-uprising frameworks that often lack conceptual, theoretical alternatives.

Ukraine's situation, dealing with most of its 'transition' more than 20 years after formal independence, does not fit easily into normative post-conflict narratives and analyses. Transitional justice, normally, has been discussed as firstly a transitional interval between two political regimes (O-Donnell and Schmitter 1986; Lyubashenko 2017, p. 20); secondly, a transition towards political liberalisation 
(Teitel 2000, p. 223); thirdly and more recently, a transition towards 'justice' rather than necessarily transition to a specific paradigm (Sharp 2013, pp. 16, 25). Transitional justice is undeniably political (Andrieu 2014, p. 89) and conceptually founded in legal positivism (Lyubashenko 2017, p. 24; Teitel 2000, p. 14). The assumption made by the legal positivism within transitional justice is that through the application of law and a 'just' legal system, order, justice, and even peace will prevail (Bix 2006).

In recent years, scholars of transitional justice, peace-building and post-conflict studies have begun to explore how transitional justice has been insufficient to respond to the complex needs of post-conflict societies (Balint et al. 2017; Miller 2008; Carranza 2008). Calls for transformative, rather than transitional, justice reflect a revised approach to create accountability whilst also addressing the root causes of conflict (Balint et al. 2017, p. 5). Transformative justice agendas include context-specific approaches that identify local social and economic needs, while also questioning what is truly transitional. Scholars call for strategies that address immediate post-conflict political and economic reconstruction as well as structural inequalities that exacerbate conflict and continue violence throughout the so-called transition period (McAuliffe 2017, p. 245; Balint et al. 2017). The grounded experience of originary sociality does not propose a direct way to attack structural inequalities and economic violence. While not diminishing the continuing violence, rather than diagnose continuities, the emphasis shifts towards original and originating ideas, perspectives and attitudes. Exploring how sociality continues out of uprising suggests an alternative tack that rejects fixed, linear frames of analysis to grapple with plural and often contradictory realities, expressions and narratives that feel anarchic. Thinking anarchically may illuminate transformations that, if enlivened, could challenge analyses and critique that remain entrenched within paradigmatic frameworks that reinforce existing structures and systems.

\section{The Revolution of Dignity}

The Revolution of Dignity - so-called to reflect the participants' new found dignity as empowered citizens (Kovtunovych and Pryvalko 2015) - began as an occupation of the main square (Maidan Nezalezhnosti) in Kyiv in November 2013. The 'tent city' in Maidan lasted until 21 February 2014, with various stages of citizen organisation and fluctuating incidents of state violence. The Maidan was a highly organised space, with volunteer-run centres (notably EuroMaidan SOS and AutoMaidan) for food, health, security, and protest training, but with no clear political leadership or political party affiliation (Interview Kyiv, 26 July; Chernivsti, 18 August 2017; Kovtunovych and Pryvalko 2015). The public stage erected regularly held rock concerts, poetry readings, an event for New Year's Eve, but barred political posturing (Shveda and Park 2016). The Maidan crystallised a resistance to the regime, whose corruption and lack of accountability characterised politics in Ukraine not only since independence in 1991, but throughout the Soviet era (Kovtunovych and Pryvalko 2015). In initially denying stage access to recognised politicians, it also reflected an anarchic rejection of official participants in the political life of Ukraine. People, 
bodies, in the square exposed a space of resistance, possibility; they demonstrated originary sociality.

On 17 January 2014, the Yanukovych government passed anti-protest laws, followed by blanket arrests, intimidation, and torture of community-protest leaders. By this time, protests were being organised not only in Kyiv but Lviv, Odessa, Kharkiv, Donetsk, Luhansk, Ivano-Frankivsk and other centres (Kovtunovych and Pryvalko 2015; Interview Kharkiv, August 2017). The anti-protest Bill, which was quickly passed through Parliament (the 'Rada' in Ukraine) by a show of hands and not the standard procedure of electronic voting, banned any unauthorised installation of tents, stages or sound systems in public places and the wearing of headgear (Verkhovna Rada 2014). The latter was resisted by people who gathered wearing pots, pans and other items on their heads as an affirmation of their 'indifference to the law' (Newman 2015, p. 69).

As a consequence of pressures mounting within the Rada, nine of the anti-protest laws restricting freedoms of assembly, headgear and so on were revoked by the end of January (Inter-fax Ukraine 2014; Verkhovna Rada 2014), however not before targeted attacks in Kyiv resulted in abductions and deaths of protestors on 22 and 23 January 2014. ${ }^{8}$ Tensions escalated. During three days in February 2014 (18-20th), over 100 protesters were killed and thousands injured. The trade union building in Maidan, which acted as an office/HQ for Maidan organisers, was set ablaze resulting in multiple deaths; the cause of the fire remains unknown. ${ }^{9}$ Between 18 February and 8 March 2014, 661 people were reported missing by the volunteer organisation EuroMaidan SOS (Chivers 2014). Additionally, protestors were killed and injured in satellite Maidan protests in Kharkiv, Odesa, Donetsk, Luhansk and Crimea. During this time of mass violence Yanukovych fled Ukraine and EU foreign ministers brokered an interim government. New presidential elections were called for May 2014. Many Maidan leaders were introduced into this new interim government, but also members of the standing opposition (i.e. existing politicians). The fear of a reestablishment of the prior status quo, voiced by some Maidan protestors organised around the Maidan Self-Defense Committee, together with questions of Europe's influence or relationship to Ukraine, was overshadowed by the events that followed in the South and East of Ukraine.

By 27 February, Russia was occupying military bases in Crimea (see Yuhas and Jalabi 2014). Russian's strategic desire for Crimea was hidden within rhetoric of restoring Nova-Rossiya and supporting the Self-Proclaimed People's Republic of Donetsk. ${ }^{10}$ While, to date, Russia avoids claiming any legal responsibility for

\footnotetext{
${ }^{8}$ At least four protestors died from gunshot wounds and firearms injuries. The first death was a 21-year old student, Serhiy Nigoyan. While official government sources claimed that only rubber bullets were being used, these deaths changed the tenor of the tent city.

9 The fire-and a similar, more deadly fire in the Odesa trade union building in May 2014 - has been used by military courts in the occupied Donetsk administrative division (oblast) to condemn protestors for supposed subversive activity.

10 At first, the Russian government denied involvement in the armed occupation of Donetsk and Luhansk. Today, direct Russian government involvement in the occupation of these Eastern oblasts is undeniable: Bill No. 7163, in Verkovna Rada of Ukraine on 6 October 2017 (first reading). Second reading postponed into 2018. Verkovna Rada Ykrainy [Parliament of Ukraine], 2017.
} 
occupied Ukrainian territories, a European Court of Human Rights decision in July 2017 held that Ukraine is also not liable for losses during the time that Ukrainian territory is not under Ukrainian government control (ECHR no. 76639/11; Kindt 2017). The lack of ownership for the events, and human rights abuses, violence and property (livelihood) damage in occupied Donetsk and Luhansk oblasts complicate attempts for a legal resolution to continuing violence (Stop Fake 2017; Plokhy 2017; Yekelchyk 2015; Kuzio 2015).

\section{Transitional Justice Mechanisms Applicable to Ukraine?}

It is impossible to quantify the transformation amongst people in Ukraine who participated in the protests in 2013-2014, or the subsequent effects upon the whole of Ukraine's society. In transitional justice approaches, 'local' organising and 'local' experience is positioned in relation to the national as if one or the other 'trickles-up' or down to inform the processes of change following a disruptive or violent conflict (McAuliffe 2017, p. 257). However, insurrection as experienced in Ukraine arguably constitutes a new local and a new political such that the local cannot be juxtaposed to the national, or government versus the people. In Maidan, governance and authority was turned on its head. Moreover, there is no distinct singular experience that can be extracted as exemplifying the transformative effect of living through the violence and common-being that happened in the square in Kyiv and around the country. Thus, in order to assess transformation and change at a local level, to challenge topdown (and foreign) approaches, analyses need to grapple with a plurality of singular experiences, not to mention a diversity of claims to identity, nationality, memory and 'official' history. ${ }^{11}$ Anarchic and originary, post-uprising Ukraine exists without a homogeneous unifying identity resultant from an insurrection of individuals, and synchronically, a collective happened and continues to be happening ever since the events of 2013-2014. This is evident in Ukraine, but presumably applies to other geographical regions, emphasising the shortcoming of normative transitional justice discourses and solutions.

Traditionally, transitional justice seeks 'clear distinctions between conflict and post-conflict periods' (Balint et al. 2017, p. 5). Ukraine does not conform to these distinctions. The popular uprising in Maidan that led to violent conflict was a battle against corruption and a lack of trust in governance (and an expression of hope that joining Europe would help rid the country of its malaise). Yet the events that followed-the ousting of President Yanukovych on 22 February 2014, the illegal Russian annexation of Crimea on 18 March 2014 (with relatively few consequences to Russia), the election of a new government in May 2014 led by President Peter Poroshenko, and the war in Ukraine's Eastern provinces of Luhansk and Donetsk,

\footnotetext{
11 A discussion of the rich histories and complexities of identity, memory/memorialising and nationality/ ethnicity, saturated with trauma and ongoing historical amnesia/denial, in Ukraine is beyond the scope of this article. See Plokhy 2008, 2015, 2017; Vyatovych 2013; Yekelchyk 2007; Hrytsak 1996; Verba and Yasen 1980.
} 
persisting since late 2014-have exposed decayed foundations supporting a weak system of governance and a population with little faith in leadership and the rule of law. ${ }^{12}$ Twenty-six years after formal independence from the USSR, the legal system remains ambiguous. Ultimately, it remains a tool for those in power to extend this power by either granting or refusing rights and recognition (Interviews Kyiv, Kharkiv, Lviv, Chernivtsi, Odesa, July and August 2017). Ukraine continues to project an aspiration to 'European' systems of governance and participation in Western market economies while entrenched oligarchic regimes firmly grip institutions of legal and political power.

Simultaneously, civil society (volunteer) organisations, communities and new non-governmental leaders are posing new challenges to this status quo. New concerns to maintain a positive international image, together with opening to foreign expertise and investment, is re-shaping government and NGO discourse (Interview Kyiv, 30 August 2017). These movements and changes, however, are not embodied or organised into one singular movement, nor do they philosophically align with Western notions of 'left' and 'right' or 'neo-liberal', 'anti-globalisation' or 'anticapitalism'. Without a singular oppositional political party to represent the move for change, or a clear Western or Eastern agenda, the transformations and changes that have occurred post-civil uprising in Ukraine are anarchic, representing evolving modes of being that are neither clearly positive nor negative. ${ }^{13}$ The possibilities of re-creating the state based from originary sociality are resolutely unknown. But if our critiques of existing mechanisms, which remain bound to quantifying transition based on legal and economic reforms, ring true (as will further be demonstrated below), then we may have little to lose and possibly much more to gain by shifting the focus of academic post-uprising analyses.

\footnotetext{
12 The meaning of the rule of law, in periods of transformation, is always complicated. In conversations in Ukraine this term was used to encapsulate the desire for a collective order grounded in principles of justice, accountability and transparency. This is different from, as has been discussed by Teitel, continuity, respect for precedent and normativity. See Teitel (2000, chapter one, pp. 11-26). My hypothesis is that legal positivist assumptions within traditional Anglo-American uses of the term 'rule of law' are not reflective of the uses of this term in Ukraine; however more detailed investigation of this is beyond the scope of this paper, and reserved for future study.

${ }^{13}$ My use of the terms 'anarchic thinking' and 'originary sociality' share similarities with other discussions of experiences that transcend liberal identities and epistemologies, for instance Ratna Kapur's 'selfsubject as a non-liberal experience' (Kapur, workshop at the University of Liverpool May 2017). See also, Kapur (2018). However, the ontological argument furthered by Nancy through his exploration of originary sociality as the constitution of communion (if not 'community') warrants deeper investigation within the context of social uprising. This article introduces the project, but the ontology underlying the jurisprudence of transformation will be pursued further in later writing.
} 


\section{Transitional Justice and International Law: Responses to Conflict and Uprising}

As the title to this article suggests, there is a presumption that a social uprising should and will lead to new legal form. Ukraine's current situation demonstrates that transitional justice policies are unlikely to be implemented and enforced (Lyubashenko 2017, p. 24). Bauchmann and Lyubashenko argue that transitional justice in Ukraine needs to be 'applied on behalf of democratisation, but also as a set of measures addressing on going conflict in the east' (2017, p. 297). This dual project of re-building a country while simultaneously fighting a war leads to the dangerous scenario articulated by the activists and lawyers contacted for this research but not considered by transitional justice scholars. Transitional justice mechanisms are commonly state-led initiatives, but where the state (Ukraine) is intent on maintaining a military force against an identified enemy, it is all the more difficult to find space for internal change and critique. In an era rife with terrorism discourse, accusations that criticism against the Ukrainian government is unpatriotic further threaten to justify limitations on freedom of speech and journalism. Respondents who were active during Maidan and continue to pursue this work fear that restrictions and covert intimidation tactics against those critical of the government (especially movement on judicial reforms) is bringing Ukraine and its citizens back to their pre-Maidan reality (Interviews in Kyiv, 26 July, 30 August; Kharkiv, 31 July; Chernivtsi, 18 August 2017; Rojansky 2016, p. 319). Combined with the lack of accountability for perpetrators of violence during Maidan and failure of prosecution, many activists are cynical about the future (Interview Kyiv, 26 July and 30 August 2017; Coynash 2017a).

Ukraine's current state of affairs is embedded in the legacy of Soviet governance structures that maintained a strong disconnect between people and law-makers, judiciary and police. The lack of civilian-led participation in governance throughout the period of the Soviet Union is perhaps one of the reasons that the uprising in 2013, which became such a fundamental turning point for many Ukrainians as well as a cause of geo-political disruption, cannot be assessed by formal economic and 'transition' indicators alone. Throughout the five cities visited during the course of this research, many people openly said that change and transformation is happening and will continue to happen, in spite of the games that presidents and 'officials' play. Interestingly, this is not directly contradictory to the cynicism of many organisers and activists. Rather, work outside of government agendas, in communities and neighbourhoods, breathes an energy that arguably fuels what otherwise would seem a losing battle inside government systems. This coexistence of change and stagnation arrests easy assessments of the Revolution of Dignity's success or failure. The movement, or lack thereof, on reforms within the government structure and judiciary suggests disconnect between governance and the Revolution's experience of people working in common to build society in spite of the state. 


\section{International Justice Mechanisms}

Transitional Justice focuses on three variables: state functionality, domestic politics, and economics in post-conflict transition. Increasingly transitional justice approaches recognise the need to seek justice and peace-building following conflict or violent civil upheaval (McAuliffe 2017, p. 33). Reforms and progress within a country are recognised as shaped inside-out, rather than by imposing an external frame onto a particular socio-cultural site. Nevertheless, international legal structures such as the ICC serve as external reference points for recognition of the violence and injustice suffered under a violent state regime.

Ukraine is not party to the Rome Statute of the ICC. In April 2014, under significant pressure from the Centre for Civil Liberties Ukraine, the Ukrainian government lodged a declaration under Article 12(3) to accept ICC jurisdiction (Interview Kyiv, 26 July 2017; see Centre for Civil Liberties 2017; ICC 2017). The ICC's first response was that the violence at the Maidan was neither systematic nor a coordinated plan of violence. By 2016, the ICC stated that they will 'continue to engage with Ukrainian authorities, civil society and other relevant stakeholders' (ICC 2017; Rojansky 2016, p. 315) to gather information relevant to the factual analysis of the situation in Ukraine-which, in the 2016 examination report, includes crimes in occupied Crimea. This has given activists some hope that eventually crimes will be prosecuted, but little consolation for immediate attention (Interview, 26 July 2017). The Ukrainian government does not deny ICC intervention; however, with the continuing conflict in the East this effort has received diminishing attention. Some more cynical observers point to the government's own lack of transparency concerning violence during the armed conflict, while others feel this is a matter of concern once there is a visible end to the conflict, not during (Interviews Kyiv, Kharkiv, Odessa, Lviv, July and August 2017).

\section{Lustration $^{14}$}

Legislation mandating the lustration of officials and public servants in police, military, parliament and the judiciary was passed in 2014, by the post-Maidan government (No. 1188 VII). Lustration aims to replace the old regime with new cadres, thereby forcing a change in practice. In the judiciary the enforcement of lustration policies has been met with opposition, in particular where convictions are to be passed by judges who were active during the time of the Maidan and thus part of the very same system they are now being called upon to condemn (Coynash 2017b). Lustration is controversial in its effectiveness; the resulting unemployment of the former members of the police force or military presents the possibility of further civil unrest. While these transitional justice mechanisms look for individual criminal prosecution or vetting, sceptics question whether these same mechanisms can address structural violence and economic crimes (Andrieu 2012; Carranza 2008;

14 See supra 6 for definition of lustration. 
Ni Aolain 2017). According to Zabyalina, lustration laws have 'prophylactic effects rather than bringing about a systemic change to which Euromaidan protestors aspired' (2017, p. 74).

The Revolution of Dignity attempted a break with oligarchic democracy (Lyubashenko 2017, p. 298). The transition that now faces Ukraine is not one of reconciliation between opposing factions. The conflict in the East continues without transitional justice on the agenda. Rather, the change forced by the civil uprising brings to light economic crimes and corruption: the cause of the country's crisis and Revolution. Judicial (including Supreme Court), police, medical, educational, and economic (pensions) reforms are being debated in parliament, the EU-Association Agreement has been signed, and significantly, new economic policies have been enacted that decentralise public funding to grant more financial autonomy to local councils. The PGOU since 2015 has been investigating dis-banned Berkut forces and Yanukovych's government. ${ }^{15}$ A new police force, mainly foreign-trained (Williams and Chornokondratenko 2016), has been established nationwide to re-shape the image and practice of law enforcement: now called поліція (politzia), rather than the former Soviet-era, міліція (militzia). Nevertheless, both the PGOU and new government officials ('new' does not include Poroshenko, an oligarch in his own right) are ensconced in layers of governance, bureaucratic and power structures. Ukraine has been characterised as transitioning from an oligarchic state into a mafia state (Kuzio 2015). While legislation has ostensibly changed and the constitution has been rewritten, in practice there has been no significant transition to a 'democratic' model. A professor I interviewed described current attempts at government reform as a soviet system with a bad makeover to appear European (Interview Kyiv, 16 December 2015). The professor wondered whether this makeover would penetrate, fade, or be stripped away due to the continuing conflict. In other words, no-one knows how to effect lasting change, beyond a veneer of transformation. On a normative level, the failure, to date, of lustration and ICC involvement suggests that importing, or training, more transitional justice experts in Ukraine (see Nuzov 2017, p. 152) is not enough. Yet beyond this, the epistemological challenge remains: how do we, activists, observers and theorists, move beyond linear measures of 'success' and 'progress'? While the lawyers, academics and activists I spoke with in Ukraine pause to consider and wonder at this challenge, the normative transitional justice thinking directs them to prioritise reforming the basic infrastructures of law and legal processes - without questioning their foundations. Thinking 'progress' and 'reform' immediately override discussions that, crucially, question the very structure and framework on which reforms are to be implemented.

\footnotetext{
15 The Office is aiming for two-fronts of criminal accountability: (1) perpetrators of direct physical violence, the Berkut and Titushki (hired thugs, directly linked to high official commanders); and (2) commanding high officials, and their economic crimes. Lyubashenko (2017, p. 50).
} 


\section{Reform of the Supreme Court}

Judicial reforms, including the creation of a new Supreme Court (Law No. 1401VIII; No. 1402-VIII) are a major concern for politicians and activists alike. Since 2016, the Public Integrity Council made up of citizens and volunteer organisations has assisted the High Qualification Commission of Judges, screening candidates to be recommended for a new Supreme Court of Ukraine. Recommendations were made in 2016/2017 for new appointments, with the aim of excluding unqualified and legally compromised judges. However, 30 of the 120 individuals identified by the High Qualification Commission of Judges did not meet the criteria of exhibiting integrity and professional ethics in their role. There is evidence to suggest that these individuals had been involved in tax evasion, undeclared income, and miscarriage of justice during the Revolution of Dignity, and had known ties with oligarchs and organised crime (Makarenko 2017). Moreover, in the screening for judges who were to be appointed to the Supreme Court, 44 individuals who did not pass the practical test were allowed to continue onto the final stage of the application process (Interview Kyiv, 30 August 2017). Poroshenko's approval of these appointments was considered a setback in the progress of reform (Sukhov 2017).

Reforms to the court system threaten to shake up the privileges and immunities enjoyed by members of the judiciary and their family and/or business partners. Examples, from losing evidence in court (bullets apparently were lost in the cases of L. Sheremeta and D. Pahor, who were killed in Maidan on 19 February 2014, see Coynash 2018) to undeniable collusion and bribery between prosecutors and defendants (the trial of Y. Krysin and other 'titushky' involved in kidnapping, carjacking, beatings and raids during Maidan and after, see Shandra 2018), intimidation and murder (most recently, the death of lawyer Iryna Nozdrovska, see Bennetts 2018) continue to disrupt progress within legal and court reform. Amendments to the Criminal Procedure Code in autumn 2017, with regard to setting up an anti-corruption court, will amend the length of time one can await charges and prosecution, making it more difficult for people to bring charges against perpetrators. Movement on this proposed amendment stalled in 2017, by also raising considerable disagreement from international funding bodies, namely the International Monetary Fund (IMF) and European Commission, whose aid package to Ukraine is contingent on progressive reforms (IMF 2017).

Indicative of how progress and its inhibitors are rarely straightforward, however, in December 2017 Poroshenko signed a decree for the 'liquidation and reorganisation of courts of different instances' (Kovalenko 2018). This restructuring of the court system across Ukraine will focus on lower courts to reduce corruption and abuses of power (these lower and appeal courts have functioned with de facto immunity). Thus, while there are many criticisms of Poroshenko's lack of action on judicial reform, this move may prove to be welcomed by many working to create a more transparent court system. 


\section{Decentralisation: A Space for Transforming Perspectives?}

Ukraine might seem to have little precedent of good management while its population, by and large, has very little faith in the rule of law (Interview Kyiv, 26, 28 July; 30 August 2017). Nevertheless, the new government (May 2014) decentralised control of budgeted funds to local councils. Decentralisation has made significant positive differences in local communities and regions (Interview Kyiv, 21 July 2017). For the first time many budgetary decisions will now be made at a local level. Potential for this localised reform is vast, reflecting the multiplicity of possibilities evoked in Nancy's originary sociality. As people come together in local communities and councils, they are creating transformation post-uprising without state control. Communities and councils with the foresight or knowledge of how to designate these funds (Interview Kyiv, 21 July 2017), and the organisation to implement change have invested in schools and infrastructure, which have been long ignored by the central authorities. Moreover, young people (the 'freedom generation'), less eager to leave Ukraine since Maidan, are finding local areas to work and nurture a new energy in Ukraine (see Chermoshecheva 2015).

The town of Podilske, for instance, has a 24-year-old leader (elected 'chairperson'). Together with the townspeople, the local council have renovated the town's cultural centre to create a hub for the community. They have used government funds, from decentralisation, to instal streetlights, where previously streets had been unlit and dangerous. The young leader affirms that people in the town are motivated by him and his age to take action themselves to make the town better, cleaner, and ecologically sound; they have even installed solar-powered lights at the eternal flame in the centre of the village (Cavchyk 2017).

In the village of Druzhnya there is a vibrant culture of volunteerism. With support from an EU-backed initiative bringing together communities with diverse populations (Roma, Armenian, Ukrainian), volunteers have sparked new life into their village, beginning with cleaning up the waterfront. This volunteer-run community project instilled a sense of ownership and pride to maintain ecological systems, village parks/green spaces and to create safe spaces for children to play. The villagers do not look to the central state for guidance and change (GURT 2015).

Similarly, a young leader, Oleksandr (Sasha) Melnyk, has invested in his village of Boguslav after his experience in Kyiv during the Revolution. Rather than stay in Kyiv or travel abroad, he felt that change needed to happen at the regional level: 'In memory of those people, we should make it so the historians in 10-20 years write: "Those events were tragic, but it changed Ukraine. It became better, more supportive" (Hirna 2017). Bogulsav now has its own newspaper; murals decorate the town; a reconstructed square provides public space; there is an open-air summer cinema; and a 'centre for support of people's initiatives' with free training, lectures and events on community action and political education. Boguslav also has strengthened its political voice by using a political tool that existed but was never used to recall deputies (members of parliament) mid-term, if they had lost the faith of their constituents (see Hirna 2017). 
The coming together of singular beings in the plural, to create common projects and common achievements is happening without oversight or mandate from government or foreign experts. This same energy brought people out to Maidan, and continues to generate action, volunteer work, dialogue and critique: again, for better or worse, not with the aim of rejuvenating a political party but with an anarchic 'aim' (that cannot even be labelled a collective 'aim') of living-living parallel to, in spite of, the state and its Law (see Loizidou 2016).

Volunteer initiatives are gaining momentum in Ukraine. Civil society has been energised (Interviews Kyiv, 21, 26 July and 30 August 2017). NGOs such as the AutoMaidan, Centre for Civil Liberties, think tanks and arts organisations are actively drawing people together, making national and international linkages to promote human rights, justice, peace, creativity, and community. However, an interviewee noted, as long as activists are reluctant to enter into political leadership positions, due in part to the difficulty of breaking into the political system, there is still a gap between the top levels of governance and what is happening in people's lives (Interview Kyiv, 30 August 2017).

The underlying problem, according to observers and analysts including those interviewed for this project, is an oligarchic leadership, with Europeanist aspirations (Sawka 2017, p. 11). Does this mean that change must occur outside of state politics? (Conversation with Y. Hrytsak Lviv, December 2015; Interview Kyiv, 21, 28 July 2017). Perhaps rather than imagining a stateless future, expectations and discourses need to shift: change is not linear, but fragmented-or rather, needs to be assessed and recognised for its movement, constantly becoming. For instance, contrary to the concern of the activist noted above, there are new, young parliamentarians in Ukraine's Rada, mainly (but not exclusively) organised in the Samopomich party (Haring 2018). Their presence in the formal ranks of the political institution, however, is just one aspect of mobilisation and movement towards political and social difference. Ukraine is also experiencing growth in foreign investment and foreign companies. The question of what to do with this reality begs new conceptual frameworks. These new conceptual frames may not be immediately adopted, or recognised, by politicians and leaders, but conceptual framing can begin within the scholarship/analysis of post-uprising contexts to challenge stale models of transitional justice.

\section{Privatisation and Economic Investment}

Transitional justice has been criticised for maintaining a guise of neutrality, while furthering the neoliberal restructuring of states (Franzki and Olarte 2013, p. 203; McAuliffe 2017, p. 204). European Commission and IMF aid funding to Ukraine (Ukraine being among the largest recipient donors since 2016) are contingent on restructuring reforms being successful. There is increasingly an acknowledgement that work to change the country, technically in governance and mentality, needs 
to happen external to 'politics' and governance-in think tanks, universities, and neighbourhoods (see Nestor Group; Nova Ukraina). Private, foreign actors are arriving in Ukraine for foreign investment opportunities as well as to fund local projects and initiatives. This is a delicate and dangerous balance. A foreign investor with whom I spoke in Odesa remarked that it is 'open season' in Ukraine: in his words, 'a virgin market ripe for investment'. His unapologetic boasting revealed that the Ukrainian government continues selective regulation, embodied in the phrase, 'For my friends, everything. For my enemies, the law. ${ }^{16}$ Foreign investors with friends in government enjoy tax-free investments, loosely regulated import and export, and preferential access to real estate. The future consequences of such investment in Ukraine are concerning, where precedents include (post-colonial) countries where foreign investment - 'a fusion of sovereign power and commercial entit[ies]' (Miles 2013, p. 41)—wrought violence, poverty and significant environmental damage (Miles 2013, pp. 31, 47). Without clear oversight and attention to the legal reforms that shape investment opportunities in Ukraine, activists fear that short term positive effects, such as funding for NGO volunteer projects, may lead to longer term problems due to unregulated foreign intervention and deregulated markets (Interview Kyiv, 26 July 2017). Thus, in spite of positive movement outside the state, activists continue to fight for legal reforms to bring justice to victims of state violence (Interview Kyiv, 30 August 2017) as well as to build a transparent, accountable legal system. Such a legal system would be an imperative element to guide investment towards a sustainable, 'socially and environmentally responsible foreign investment' (Miles 2013, p. 351) regime that takes into account, rather than discounts, local citizens and business interests (Hundar 2017).

The opening up of the Ukrainian economy to foreign investment, in other words the neo-liberal marketisation of the Ukrainian state, may be inevitable in the immediate present. Nevertheless, critical scholars such as Miles, Michalowski and Sattorova suggest investment needs to be managed by conscientious local, national and international policy and lawmakers. The possibility remains to build a system, particular to the contexts emerging from the former Soviet Union, distinct from the formulaic governance imposed via a global market economic system built on a dysfunctional national structure (see Michalowski 2018; Sattorova 2015). Engaging with the local brings us back to attentiveness to the originary potentiality of the social-that exists, but is denied within the repetition of conventional, traditional forms of analysis (e.g. transitional justice) and critique (e.g. searching to 'fit' postuprising into categories of failure or success, and/or assessing succession as either left-wing or right-wing). This involves recognising the sociality as an anarchic space that is generative, originary and happening.

\footnotetext{
${ }^{16}$ Óscar Benavides, President, Peru 1933-1939. Cited in conversation with a Ukrainian-Canadian working in Kyiv, 27 July 2017.
} 


\section{Legal form After Uprising: Re-assessing Transformation}

The assessment of a legal framework to be reformed or rule of law to be strengthened poses both a question and reveals a presumption. From social uprising to legal form can be a logical assumption as well as a legislative challenge. It is also an epistemological assumption that leads to an ontological challenge, when the statement is read via post-structuralist understandings of law as a dynamic limit that is formed and constantly challenged and de-formed by a sociality - a coming together of persons in common, originary in every encounter. The legal form after a social uprising is informed not only by a sociality which is radically different from what it was before, it is unique to the specificity of the bodies, the material experiences, that both demanded and experienced change at a singular, local, community, institutional, state and psychological (individual and collective) level. This is radically different from exploring and critiquing the law as an externally constructed limit that constitutes its subjects and thereby can be something that is reformed (externally) and implemented following civil unrest and upheaval in governance personnel. Anarchist thinking, or thinking anarchically, contributes to such a re-conceptualisation of order and law. The premise of thinking anarchically is opening onto the multiplicity of experiences not to reveal fragmentation or disjuncture, but to situate meaning as originating from the experiences that are singular but experienced (enabled) only in the plurality of these singular experiences. This is anarchic because the 'happening' transcends predetermined frameworks and order. Equally, in thinking of these experiences, the thought process can only be conceptualised as being open to thinking anarchically: thinking beyond boundaries, labels and definitions.

Such a way of thinking is not an exercise in lawlessness; it is re-thinking law at its foundation: what are the constituent elements of law? What is the purpose of the law? What is the limit that a sociality identifies? Thinking anarchically illuminates Nancy's originary sociality - the happening, the experience, that disrupts form and predetermination. Anarchic ontology looks for the immediacy of present expressions of freedom from the state, through an affirmation of self and life (Newman 2015 , pp. 67, 138). The presence of thousands of people in the square, living, sleeping, playing music through all weather is what Newman describes as an 'intrusion of naked life into the political realm' (Newman 2015, p. 58). It is unprecedented, non-conformist and intrinsically different from traditional liberal democratic action. Thinking anarchically applies to thinking of 'state' away from the state, in order to constitute, albeit theoretically at first, a new concept of what, and who, constitute the state. This maps onto Jean-Luc Nancy's originary sociality as it captures the multiplicity of people coming together in common to function as a sociality, randomly, materially and without predetermination (Newman 2015, p. 39). The anarchic movement of difference and activity that is happening in Ukraine itself, on a local, regional and personal level, prevents one from claiming that there is no change; the originary sociality is constantly forming, un-forming and deforming.

The Revolution of Dignity was not an uprising calling for individual civil rights or individual recognition (Interviews Kyiv, 26, 28 July 2017). The rallying cry was not for individual rights as understood in the context of civil rights movements, but 
rather for governance over a collectivity of individual persons deserving of dignity, fair treatment and accountability (Kovtunovych and Pryvalko 2015; Minikow 2016, p. 5). This desire, this collective call for dignity, sparked a collective mass-movement against a governmental regime. Currently, as the new government exercises its power and as the violence in the Eastern regions continues, it is difficult to claim that much has changed in the day-to-day administration of Ukraine. If anything, aggression has heightened. Judgements of 'success' or a 'successful transition' are largely negative. As a man in Kharkiv stated when I asked him whether he felt that the country had changed after EuroMaidan, "500 years of occupation ... so what is the change now? We are here. We are still here. We never thought we'd be here 2-years after being beaten in a gathering by that Shevchenko monument. ${ }^{17}$ But we are here. Who knows what will come after this. But we are still here' (Kharkiv, 31 July 2017). One could look at this statement and see that structural change is slow, if not impossible. Such an assessment of change and transition comes from a largely deterministic transitional paradigm (Lyubashenko 2017, p. 35) that looks for the establishment of common legal standards and measures. This frame too easily overlooks the change within a population that lived through Maidan: 'We are still here.' How has the 'being here' affected people's priorities of information and knowledge? New discourses of dignity and rights are blossoming in think tanks, NGOs, universities, cafes, and even advertising, in post-Maidan Ukraine - what will be their movement?

In describing ontological anarchy Newman, drawing on Walter Benjamin, suggests that violence and conquest are crystallised when a 'peaceful coexistence [is] achieved by the state' (2015, p. 72). The continuing turmoil in Ukraine, including disagreements and lack of consensus on historical memory and memorialisation of Maidan exposes the impossibility of peaceful transition emerging within a context of structural, economic and physical violence. Studies of post-conflict and transitional justice can often shift attention from 'apparent exceptionalism of abuses in conflict to the normality of ongoing structural violence' (Maddison and Sheperd 2014 , p. 264). In order to be effective or offer difference to post-conflict situations, the complexities of lived experiences that contradict and confuse progressive, positivist narratives cannot be denied.

Thus, the current situation in Ukraine is not a return to old regimes. Such claims arguably serve to resurrect a past that no longer exists (Interview Kyiv, 30 August 2017). Neither is Ukraine lost in power-struggles with Russia in an on-going war that may be perpetuated by inflexible and financial interests on both sides (Economist 2017). Global communication, media and financial interests and exchanges condition a different present and future. An alternative analysis of change and transformation through originary sociality suggests that the change that is happening in Ukraine is a continuum of transformation, as suggested by the opening quotation, which is intellectual and psychological as much as it is about reforming judicial systems and governance. Thinking 'transformation' differently opens onto a mess of

17 The satellite Maidan protest in Kharkiv was a gathering at the Taras Shevchenko (famous $19^{\text {th }}$ century Ukrainian poet), monument in the centre of the city. 
narratives, complexity of causes and a plurality of ideas of futures, resolutions and justice. Analyses that look for order, for the right narrative, or the right moment for a nation such as Ukraine to transition into a liberal, democratic order respond to a vastly different orientation; thinking anarchically calls for an ongoing re-configuration of our epistemological frames.

\section{Anarchist Thinking}

Critical approaches to law reveal how law is 'fundamentally concerned with the construction and anchoring of value' (Otomo 2016, p. 16). Here, value and relevance come from enforcing judgement in order to bring, keep and/or restore order. ${ }^{18}$ The acts of judgement, in making laws and their 'practice' create a tangible site and a reality wherein justice can be materialised, or made to exist (Otomo 2016, p. 89). Yet one does not have to look far to see how these sites have not resulted in tangible justice, change or order, neither in Ukraine nor in many other spaces and times. In Ukraine, laws have been passed to bring about change (e.g. lustration law), to little effect. The Supreme Court has been restructured, yet 33 appointees failed the practical element of their tests. The court system is being restructured and many lower courts liquidated, yet on 1 January 2018 Iryna Nozdrovska's body was found mutilated in an act linked to her activism calling for justice (see Bennetts 2018). How are the struggle for legal reform and the struggle for justice in Ukraine more than performances that fail to reflect any of the change that was called for by the people in Maidan? How can the people who lived through the violence in the square in February 2014, or the thousands of dead or wounded in Donetsk and Luhansk, and millions of persons internally displaced from Donbas and Crimea, find any relief in the actions taken or denied by the 'new' government since 2014?

To this, there are no easy answers. However, thinking anarchically is, at its core, a challenge to the status quo of stagnant power and the manufactured hubris and superiority of international law. Anarchic thinking is not a 'counter' but a platform for a plurality in singular beings. ${ }^{19}$ This plurality already exists, but is regularly silenced, denied and neglected. Saul Newman explores the experience of anarchy that is not an impossible, nihilistic move, but a freeing moment, that 'frees action from its telos' (Newman 2015, p. 10). This kind of ontological anarchy has no predetermined ends, unlike anarchism as a philosophy theorised by writers such as Proudhon (1847) who sought to substitute political authority with an alternative. Ontological anarchy suggests an anarchistic thinking as a movement, an opening onto a thinking that dislodges from the very framework of analysis towards the other-already-happening.

Thinking anarchically seeks to see life before it is translated or structured by a very Western, ostensibly universal, law. The language of law - be it the frame of the legal trial, the language of victimhood and criminality that seeks out individual

\footnotetext{
18 Judgement understood as: 'falling in love with the fantasy that the law returns life to its origin' Otomo (2016, p. 17).

19 In fact, the singular cannot be separated from the collective because it knows itself (as singular) only through a plurality of other singular beings. Nancy (2000).
} 
perpetrators, or the legal international field that frames trade and investment agreements according to indices of democratisation - universalises experiences and histories to reign judgement of good and evil, right and wrong, on each particular case, country, and transformative event. This 'law' extinguishes the energy of movements and threatens to subsume the energy in Ukraine post-Maidan to bland discourses and measures of transition and justice. Reform to ministries and governance are undoubtedly necessary. However, before the success or failure of these reforms is captured within the language of internationalised law and international agreements, there is messiness, and a multiplicity of variables, contingencies and actors that need to be illuminated.

Speaking to people about transformation and change in five cities of Ukraine portrays an electric conceptual space, where critiques of both 'western' 'democratic' and 'corrupt' 'Soviet' fall short of what is possibly a truly unique institutional life. There is life lived parallel to the law everywhere that resists the very temporality and judgement that the Law claims to authoritatively wield (see Loizidou 2018). This life parallel to law offers the possibility of alternative expressions, whether of grief, tragedy, or structural-institutional complicity in atrocity and violence. An experience of anarchy moreover is a turbulent experience of love and compassion that can never be captured in an order sought through law and state. In these years following the Revolution of Dignity, this experience is at the surface of life in Ukraine.

\section{Concluding Thoughts}

The notion that from social movement comes, or should come, legal form, is a one-dimensional, restrictive frame circumscribing analysis and the exploration of upheaval amongst the population of a nation-state. It may seem that revolutions without a plan, or lacking affiliation to a particular political regime meant to replace the old, inevitably fail. Moreover, any replacement government or leadership may cause more damage or perpetuate the status quo that they were meant to replace. But these conclusions of 'failure' or lack of lasting success follow a progressive narrative that attempts to capture an anarchic movement - the insurrection - into a framework that the movement, at its very foundation and constitution, exists to resist. The anarchic movement at the core of uprising, such as that which occurred and persists amongst people in Ukraine, resists categorical evaluations of an uprising as a success or a failure. The mess of uprising, and the mess that follows, including the contradiction of 'transition' and 'reform' repeating the same systems they were meant to replace, need to be taken as a starting point. This starting point includes, rather than places in a hierarchy, the contradictions and transformations that occur at a local, individual and collective level as well as at a structural, governance level.

Economic crimes, corruption and a significant lack of accountability, transparency and judicial process caused Ukraine's systemic crisis and Revolution (Bachmann and Lyubashenko 2017, p. 307). Yet, lustration and other transitional justice mechanisms have failed (Zabyelina 2017, pp. 70-72). Therefore, the 'anarchic' energy of the Revolution which allowed many in Ukraine to claim their 'dignity', 
that is, their right to have agency within their society, must be acknowledged. Reform efforts in Ukraine must focus on building trust in a legal system and accountability into institutions of governance (Lyubashenko 2017, p. 157). To do this the society needs to value the reforms occurring parallel to governance structures and systems. There is no single successful true reform. In order to assess the success of the goals of Ukraine's Revolution of Dignity in effecting 'change', we must be cognisant of the originary sociality and generative anarchy of social uprising; we must recognise people affected not only by violence, but also by their collective being.

Acknowledgements This project was funded by the Alexander and Helen Kulahyn Endowment Fund and the Dr Iwancia and Mysko-Iwancia fund; Canadian Institute of Ukrainian Studies, University of Alberta; and the University of Liverpool Research Development Fund. With sincerest thanks to all the respondents who shared their thoughts, experiences and friendship with me during two research trips in Ukraine-December 2015, July-August 2017. Special thanks to Lana Kubin, Paul Niland, Inna Tserkova, Dariya Orlova, Roman Maselko, Vitaly Tytych, Yevgen Zakharov and Yaroslav Hrytsak for their ongoing support of this research. Thank you to Marusia Truchan, Myroslaw Tataryn, Seán Columb and Padraig McAuliffe for conversations and comments on previous drafts. Thank you also to Valerie Kelley, and the helpful comments made by anonymous reviewers.

Open Access This article is distributed under the terms of the Creative Commons Attribution 4.0 International License (http://creativecommons.org/licenses/by/4.0/), which permits unrestricted use, distribution, and reproduction in any medium, provided you give appropriate credit to the original author(s) and the source, provide a link to the Creative Commons license, and indicate if changes were made.

\section{References}

Andrieu, Kora. 2012. Dealing with a 'new' grievance: Should anticorruption be part of the transitional justice agenda? Journal of International Human Rights 11 (4): 537.

Andrieu, Kora. 2014. Political liberalism after mass violence: John Rawls and a 'theory' of transitional justice. In Transitional justice theories, ed. Susanne Buckley-Zistel, Teresa Koloma Beck, Christian Braun, and Friederike Mieth, 85-104. London: Routledge.

Bachmann, Klaus, and Igor Lyubashenko. 2017. The puzzle of transitional justice in Ukraine. International Journal of Transitional Justice 11: 297-314.

Balint, Jennifer, Kristian Lasslett, and Kate Macdonald. 2017. 'Post-conflict' reconstruction, the crimes of the powerful and transitional justice. State Crime Journal 6 (1): 4-12.

Bix, Brian. 2006. Legal positivism and 'explaining' normativity and authority. American Philosophical Association Newsletter on Philosophy and Law 5 (2).

Brinkerhoff, Derick W. 2005. Rebuilding governance in failed states and post-conflict societies: Core concepts and cutting themes. Public Administration and Development 25 (1): 3-14.

Buckley-Zistel, Susanne, Teresa Koloma Beck, Christian Braun, and Friederike Mieth (eds.). 2013. Transitional justice theories. New York: Routledge.

Butler, Judith. 2018. 'Enduring and broken time' a conversation between Judith Butler and Lisa Baraitser. Birkbeck University of London.

Carranza, Rafael. 2008. Should transitional justice engage with corruption and economic crimes? International Journal of Transitional Justice 2 (3): 310-330.

Economist. 21 January 2017. Ukraine's conflict with Russia is also financial. The Economist. https ://www.economist.com/news/business-and-finance/21714931-russia-may-extract-3bn-ukraineukraines-conflict-russia-also. Accessed 14 Dec 2018.

Franzki, Hannah, and Maria Carolina Olarte. 2013. Understanding the political economy of transitional justice. In Transitional justice theories, ed. Susanne Buckley-Zistel, Teresa Koloma Beck, Christian Braun, and Friederike Mieth. London: Routledge.

Geertz, Clifford. 1973. Interpretation of cultures. New York: Basic Books. 
Hrytsak, Yaroslav. 1996. Essays in Ukrainian history: Making of modern Ukrainian nation, history and interpretation. Kyiv: Lviv.

Kapur, Ratna. 2018. Conversations with law's others. In Research handbook on the politics of transnational law: Contestations-knowledges-geographies, ed. Peer Zumbansen. Cheltenham: Edward Elgar Press. (forthcoming).

Kovtunovych, Tetiana, and Tetiana Pryvalko (eds.). 2015. Maidan vid pershoi osoby: 45 istorii Revoliutsii gidnosti [Maidan from the first person: 45 Stories about the Revolution of Dignity]. Kyiv: KIS.

Kulyk, Volodymyr. 2017. Identity in transformation: Russian speakers in Post-Soviet Ukraine. EuropeAsia Studies, 1-23. https://www.tandfonline.com/doi/abs/10.1080/09668136.2017.1379054. Accessed 27 Nov 2018.

Kuzio, Taras. 2015. Ukraine: Democratisation, corruption and the new Russian Imperialism. California, CO: Praeger.

Loizidou, Elena. 2016. Unpublished discussions from workshop. From social movement to legal form, 5-6 June 2016. Liverpool: University of Liverpool.

Loizidou, Elena. 2018. Love, law and anarchism. In Law and philosophy: Critical intersections, ed. Thanos Zartaloudis. London: Rowman and Littlefield. (forthcoming).

Lyubashenko, Igor. 2017. Transitional justice in post-Euromaidan Ukraine. Frankfurt: Peter Lang Edition.

Maddison, Sarah, and Laura Sheperd. 2014. Peacebuilding and the postcolonial politics of transitional justice. Peacebuilding 2 (3): 253-269.

Marples, David, and Frederick Mills (eds.). 2015. Ukraine's Euromaidan: Analyses of a civil revolution. Stuttgart: ibidem Press.

McAuliffe, Padraig. 2017. Transformative transitional justice and the malleability of post-conflict states. Cheltenham: Edward Elgar.

Michalowski, Sabine (ed.). 2018. Corporate accountability in the context of transitional justice. New York: Routledge.

Miles, Kate. 2013. Origins of international investment law. Cambridge: Cambridge University Press.

Miller, Zinada. 2008. Effects of invisibility: In search of the 'economic' in transitional justice. The International Journal of Transitional Justice 2 (3): 266-291.

Minikow, Mykhailo. 2016. Euromaidan, war, and the development of Ukraine's political system in 20142015. Rimlands, buffer zones and great power rivalry: Ukraine conference papers. New York: Institute of War and Peace Studies, Columbia University Press.

Nancy, Jean-Luc. 1991. Inoperative community. Minnesota: University of Minnesota Press.

Nancy, Jean-Luc. 2000. Being singular plural. California: Stanford University Press.

Newman, Saul. 2015. PostAnarchism. Cambridge: Polity Press.

Ni Aolain, Fionnuala. 2017. After things fall apart: Challenges for transitional justice futures. Human Rights and International Legal Discourse 11 (1): 1-33.

Nuzov, Ilia. 2017. Dynamics of collective memory in the Ukraine crisis: A transitional justice perspective. International Journal of Transitional Justice 11 (1): 132-153.

O-Donnell, Guillermo, and Phillippe Schmitter. 1986. Transitions from authoritarian rule. Baltimore: John Hopkins University Press.

Otomo, Yoriko. 2016. Unconditional life: The postwar international law settlement. Oxford, New York: Oxford University Press.

Plokhy, Serhii. 2008. Ukraine and Russia: Representations of the past. Toronto, Buffalo, London: University of Toronto Press.

Plokhy, Serhii. 2015. The gates of Europe: A history of Ukraine. Philadelphia: Basic Books.

Plokhy, Serhii. 2017. Lost kingdom: The quest for empire and the making of the Russian nation. Philadelphia: Basic Books.

Proudhon, Pierre-Joseph. 1847. System of economical contradictions: or, Philosophy of poverty, trans. Tucker, B.R. (1888). Centaur Editions.

Reid, Anna. 1997/2015. Borderlands. London: Weidenfeld \& Nicolson.

Rojansky, Matthew. 2016. Ukraine-Russia conflict: A way forward. Security and Human Rights 27 (3-4): 315-325.

Sattorova, Mavluda. 2015. Between regional harmonization and global fragmentation? The variable geometry and geography of investment treaty law through the prism of regulatory flexibility provisions. In Investment treaty law current issues Volume V: The regionalization of international investment treaty arrangements, ed. N. Calamita and M. Sattorova, 277-305. London: British Institute of International and Comparative Law. 
Sawka, Richard. 2017. The Ukraine syndrome and Europe. The Soviet and Post-Soviet Review 44 (1): 9-31.

Sharp, Dustin (ed.). 2013. Justice and economic violence in transition. New York: Springer.

Shveda, Yuriy, and Joung Ho Park. 2016. Ukraine's Revolution of Dignity: The dynamics of Euromaidan. Journal of Eurasian Studies 7 (1): 85-91.

Teitel, Ruti. 2000. Transitional justice. New York: Oxford University Press.

Verba, Lesya, and Bohdan Yasen (eds.). 1980. The human rights movement in Ukraine: Documents of the Ukrainian Helsinki Group. Baltimore: Smoloskyp.

Verkhovna Rada. 2014. Закон України; 732-vii 28.01.2014; 721-vii 02.02.2014 [Online]. http:// zakon4.rada.gov.ua/laws/show/721-vii. Accessed 14 Dec 2018.

Vyatovych. 2013. 'The role of civil society in preserving Ukrainians' national memory' [Online] http:// kmfoundation.org/2013/6927. Accessed 14 Dec 2018.

Yekelchyk, Serhy. 2007. Ukraine: Birth of a modern nation. New York, Oxford: Oxford University Press.

Yekelchyk, Serhy. 2015. The conflict in Ukraine: What everyone needs to know. New York: Oxford University Press.

Zabyelina, Yuliya. 2017. Lustration beyond decommunization: Responding to the crimes of the powerful in Post-Euromaidan Ukraine. State Crime 6 (1): 55-79.

\section{News Articles and Reports}

Bennetts, Marc. 4 January 2018. Ukraine: killing of lawyer sparks protests against criminal system. The Guardian. London.

Byrluk, Olena, Natalia Shapovalova, and Katherina Zarembo. 15 November 2017. Громадянське суспільство після Євромайдану: що змінилося? [Civil Society after EuroMaidan: what has changed?] Ukrainska Pravda. Kyiv.

BBC News. 17 January 2014. Ukraine's President signs Anti-Protest Bill into law. BBC News. http:// www.bbc.com/news/world-europe-25771595. Accessed 28 Nov 2018.

Cavchyk, Irena. 5 August 2017. Наймолодший голова села: Я завжди хотів здійснювати мрії інших людей [The youngest chairperson of a village: I always wanted to help fulfil the dreams of other people] Ukrainian Interest. https://uain.press/regions/najmolodshyj-golova-sela-yazavzhdy-hotiv-zdijsnyuvaty-mriyi-inshyh-lyudej/. Accessed 28 Nov 2018.

Chermoshecheva, N. (ed.). 2015. 'Громадські ініціативи - рушійна сила змін у громаді Збірка кращих практик локальних проектів [Citizens initiatives-power of change in society, a collection of local project best practices]' Project 'New Generation': Kherson, Ukraine.

Chivers, C.J. March 9, 2014. A Kiev Question: What Became of the Missing? New York Times. New York, USA.

Conant, Eve. 2 May 2014. Ethnic Russians: Pretext for Putin's Ukraine Invasion? National Geographic. https://news.nationalgeographic.com/news/2014/05/140502-russia-putin-ukraine-geogr aphy-crimea-language/. Example of Ukraine as divided East/West. Accessed 11 Feb 2018.

Coynash, Halyna. 2017a. Return to selective justice feared in Ukraine over prosecution of anti-corruption activist. Kharkiv Human Rights Protection Group (KHRPG): Kharkiv, Ukraine.

Coynash, Halyna. 2017b. Suspended sentence: Savage murder of Maidan journalist. Kyiv Post. Kyiv.

Coynash, Halyna. 14 August 2018. Prosecutor 'loses' critical evidence regarding Khmelnytsky Maidan killings. Kharkiv Human Rights Protection Group. Kharkiv.

GURT Resource Centre. 18 March 2015. 'Дружня: Ми відновили набережну, а насправді - «оживили »село [Druzna: we restored the embankment and in fact - revitalised the village' Ukraine]. http://governance.org.ua/cult/druzhnya-my-vidnovyly-naberezhnu-a-naspravdi-ozhyv yly-selo/. Accessed 28 Nov 2015.

Haring, Melinda. 10 January 2018. Ukraine has plenty of young principled genuinely European oriented politicians. Ukraine Alert. Washington, DC: Atlantic Council.

Hirna, Darka. 21 February 2017. 3 Years after Maidan: The story of Oleksandr Melnyk. Hromadkse. Kyiv.

Hundar, Andy. 15 November 2017. Reforms: Ukraine deserves a better legal system that protects businesses. Business Ukraine. Kyiv. 
IAP, The International Advisory Panel report of March 2015. Report on Maidan Investigations. Council of Europe office in Ukraine. Kyiv, Ukraine. https://www.coe.int/en/web/kyiv/report-on-maida n-investigations. Accessed 28 Nov 2018.

Interfax-Ukrainian News Agency. 3 February 2014. Law on scrapping January 16 legislation published in Ukraine. Interfax-Ukrainian News Agency. Ukraine http://en.interfax.com.ua/news/ general/188419.html. Accessed 28 Nov 2018.

International Criminal Court. 2017. Report on preliminary examination activities: Ukraine (ongoing). https://www.icc-cpi.int/iccdocs/otp/161114-otp-rep-PE_ENG.pdf. Accessed 28 Nov 2018.

IMF, International Monetary Fund European Department. 4 April 2017. Ukraine receives IMF support but must accelerate reforms. Washington, DC: IMF.

IMF, International Monetary Fund European Department. 6 December 2017. Statement on the efforts to fight corruption in Ukraine, Press Release no. 17/473. IMF: Washington D.C.

Kindt, Eline. 26 October 2017. Non-execution of a pilot judgement: ECHR passes the buck to the committee of ministers in Burmych and others v. Ukraine. Strasbourg Observers. Strasbourg. https://strasbourgobservers.com/2017/10/26/non-execution-of-a-pilot-judgment-ecthr-passe s-the-buck-to-the-committee-of-ministers-in-burmych-and-others-v-ukraine/. Accessed 28 Nov 2018.

Kovalenko, Oksana. 9 January 2018. Олексій Філатов про те, що буде зі справами Майдану та Януковича після ліквідації судів [Oleksi Filatov about what will be of Maidan and Yanukovych after the liquidation of the courts]. Ukrainska Pravda: Kyiv.

Malynovska, Olena. 2016. Migration in Ukraine: Facts and figures. International Organisation of Migration. Kyiv. http://www.iom.org.ua/sites/default/files/ff_eng_10_10_press.pdf. Accessed 28 Nov 2018.

Makarenko, Olena. 30 September 2017. Commission recommends tainted judges to Ukraine's new Supreme Court, ignoring disapproval of society. Euromaidan Press: Kyiv.

Popova, Maria, and Vincent Post. 9 April 2014. What is lustration and is it a good idea for Ukraine to adopt it? Washington Post. Washington, DC.

Stop Fake. 15 September 2017. Three things you should know about RT and Sputnik. Ukraine. https ://www.stopfake.org/en/three-things-you-should-know-about-rt-and-sputnik/. Accessed 28 Nov 2018.

Shandra, Alya. 1 January 2018. De facto acquittal for Euromaidan murder highlights everything that is wrong with Ukrainian justice. Euromaidan Press. Kyiv.

Sukhov, Oleg. 11 November 2017. Update: Poroshenko appoints 25 judges accused of graft, unlawful rulings to Supreme Court. Kyiv Post. Kyiv.

Verkovna Rada Ykrainy [Parliament of Ukraine]. 6 October 2017. Проект Закону про особливості державної політики із забезпечення державного суверенітету України над тимчасово окупованими територіями в Донецькій та Луганській областях' [Project of the Law on territorial autonomy and protection of the state sovereignty of Ukraine in the temporarily occupied territories of Donetsk and Luhansk bblasts]. http://w1.c1.rada.gov.ua/pls/zweb2/webpr oc4_1?pf3511=62677. Accessed 28 Nov 2018.

Walker, Shaun. 18 December 2013. Vladimir Putin offers Ukraine financial incentives to stick with Russia. The Guardian. London.

Williams, Matthias, and Margaryta Chornokondratenko. 17 May 2016. New police force finds old habits die hard in Ukraine. Reuters. Kyiv.

Yuhas, Alan, and Raya Jalabi. 7 March 2014. Ukraine crisis: Why Russia sees Crimea as its naval stronghold. The Guardian. London.

\section{Case Law and Statute}

Denisov v. Ukraine (no. 76639/11) European Court of Human Rights. Grand Chamber hearing, Strasbourg, France. 18 October 2017.

Law of Ukraine No. 1188 VII for judicial reform. 2014.

Law of Ukraine No. 1401-VIII 'On Amendments to the Constitution of Ukraine (Regarding Justice). 2016.

Law of Ukraine No. 1402-VIII 'On the Judicial System and Status of Judges'. 2016.

Law of Ukraine No. 1682-VII ‘On Government Cleansing' (Lustration Law). 2014. 


\section{Other}

Centre for Civil Liberties. http://civicsolidarity.org/member/155/center-civil-liberties.

Nestor Group, nestorgroup.org.

Nova Ukraina, novaukraina.org.

\section{Interviews}

Kyiv, Ukraine:

December 2015.

July 2017.

July 2017.

July 2017.

August 2017.

Kharkiv, Ukraine:

July 2017.

August 2017.

Lviv, Ukraine:

December 2015.

August 2017.

August 2017.

August 2017.

Chernivsti, Ukraine:

August 2017.

Odesa, Ukraine:

August 2017.

Publisher's Note Springer Nature remains neutral with regard to jurisdictional claims in published maps and institutional affiliations. 